Russia stated that the treaty "makes it possible to maintain the transparency and predictability of strategic relations between Russia and the United States and to support global strategic stability." ${ }^{6}$ With New START now set to expire on February 5, 2026, the United States and Russia will have to revisit their arms control regime shortly after the next U.S. presidential election.

Other governments reacted positively to the treaty's extension. China praised the agreement as "conducive to safeguarding global strategic stability and international peace and security" and hoped that it would contribute to "ultimate comprehensive and complete nuclear disarmament." 57 The European Union emphasized the treaty "as a crucial contribution to international and European security," 58 while Japan "welcome[d]" the extension. 59

Domestic reactions largely tracked party lines, with Republicans criticizing Biden's failure to secure concessions from Russia ${ }^{60}$ and Democrats supporting the treaty's value as an arms control mechanism. ${ }^{61}$

More steps toward international reengagement will likely follow these initial moves. During the campaign, for example, Biden pledged to host a global "Summit for Democracy" and expressed a willingness to revive the Joint Comprehensive Plan of Action nuclear deal with Iran. ${ }^{62}$ Such efforts may prove more complicated than the administration's early reversals of its predecessor's actions and policies.

\title{
INTERNATIONAL Human RightS AND HuMANITARIAN LAW
}

\section{Trump Grants Clemency to Former Blackwater Contractors Convicted of War Crimes in Iraq and Associates Prosecuted Following the Mueller Investigation}

doi:10.1017/ajil.2021.13

In the final months of his administration, President Donald Trump issued a variety of pardons and commutations, including a number related to foreign relations. His decision to issue

${ }^{56}$ President of Russ. Press Release, Law Ratifying Agreement on Renewing the Treaty Between Russia and the United States on Measures for the Further Reduction and Limitation of Strategic Offensive Arms (Jan. 29, 2021), at http://en.kremlin.ru/events/president/news/64949 [https://perma.cc/C5C4-GQ79].

${ }^{57}$ China Ministry of Foreign Aff. Press Release, Foreign Ministry Spokesperson Hua Chunying's Regular Press Conference on January 22, 2021 (Jan. 22, 2021), at https://www.fmprc.gov.cn/mfa_eng/xwfw_665399/ s2510_665401/t1847956.shtml [https://perma.cc/E7T3-QQ8P].

${ }^{58}$ Eur. Council Press Release, New START Extension: Declaration by the High Representative on Behalf of the European Union (Feb. 3, 2021), at https://www.consilium.europa.eu/en/press/press-releases/2021/02/03/newstart-extension-declaration-by-the-high-representative-on-behalf-of-the-european-union [https://perma.cc/ 9 Y9G-X9VB].

${ }^{59}$ Japan Ministry of Foreign Aff. Press Release, Regarding the Extension of the New START Treaty (Statement by Foreign Minister Toshimitsu Motegi) (Feb. 4, 2021), at https://www.mofa.go.jp/press/release/ press3e_000164.html [https://perma.cc/484X-WGQK].

${ }^{60}$ See, e.g., Sen. James Inhofe Press Release, Inhofe Statement on Extension of New START Treaty (Feb. 4, 2021), at https://www.inhofe.senate.gov/newsroom/press-releases/inhofe-statement-on-extension-of-new-starttreaty [https://perma.cc/FLJ9-LN3P].

${ }^{61}$ See, e.g., Sen. Bob Menendez Press Release, Menendez Praises Biden Administration's Plan to Fully Extend New START Treaty, Encourages Biden to Challenge Russian Malign Activities (Jan. 21, 2021), at https://www. foreign.senate.gov/press/ranking/release/menendez-praises-biden-administrations-plan-to-fully-extend-newstart-treaty-encourages-biden-to-challenge-russian-malign-activities- [https://perma.cc/RVE3-73BA].

${ }^{62}$ Biden, supra note 1. 
full pardons to four former Blackwater contractors, who were convicted of killing Iraqi civilians in the 2007 Nisour Square incident, drew particular condemnation and continued a pattern of clemency grants related to war crimes committed abroad. Trump also granted clemency to his former national security advisor, Michael Flynn, and other associates who were convicted as a result of Special Counsel Robert S. Mueller III's investigation into Russian interference in the 2016 presidential election. Additionally, Trump pardoned the Israeli handler of Jonathan Pollard, a convicted U.S. spy.

Article II, Section 2 of the U.S. Constitution gives the president "power to grant reprieves and pardons for Offenses against the United States, except in cases of impeachment." ${ }^{1}$ This authority has been interpreted broadly to include offenses committed in foreign countries against non-U.S. citizens, if prosecuted by the United States. ${ }^{2}$ With limited exceptions, U.S. presidents have not interjected themselves into cases involving military personnel whose underlying offenses constitute war crimes. ${ }^{3}$ President Trump departed from this pattern in 2019, granting full pardons to First Lieutenant Michael Behenna, who had been convicted of murdering an Iraqi detainee; Lieutenant Clint Lorance, who had been convicted of murdering Afghani villagers; and Major Mathew Golsteyn, who was still pending court-martial for the murder of a suspected Afghan bomb-maker. ${ }^{4} \mathrm{He}$ also granted clemency to Chief Petty Officer Edward Gallagher, who had been convicted of taking a "trophy photo" with the body of an ISIS fighter. ${ }^{5}$

In the final two months of his administration, Trump granted a wave of clemency requests. ${ }^{6}$ While presidents often issue pardons and commutations at the end of their term, ${ }^{7}$ the recipients of Trump's clemency grants and the atypical process that he used to vet cases were controversial. The U.S. Department of Justice's pardon attorney is generally tasked with "receiv[ing] and review[ing] all petitions for Executive Clemency ..., initiat[ing] and direct[ing] the necessary investigations, and prepar[ing] a report and

${ }^{1}$ U.S. ConsT., Art. II, $\$ 2$.

${ }^{2}$ Jean Galbraith, Contemporary Practice of the United States, 114 AJIL 288, 310 (2020).

${ }^{3} I d$.

${ }^{4} I d$. at 307-09 (discussing Trump's 2019 war crimes-related clemency grants).

${ }^{5}$ Id.

${ }^{6}$ White House Press Release, Statement from the Press Secretary Regarding Executive Grant of Clemency for General Michael T. Flynn (Nov. 25, 2020), at https:/trumpwhitehouse.archives.gov/briefings-statements/statement-press-secretary-regarding-executive-grant-clemency-general-michael-t-flynn [https://perma.cc/4S8T-ZJFR] [hereinafter Flynn Pardon]; White House Press Release, Statement from the Press Secretary Regarding Executive Grants of Clemency (Dec. 22, 2020), at https://trumpwhitehouse.archives.gov/briefings-statements/statementpress-secretary-regarding-executive-grants-clemency-122220 [https://perma.cc/6PBR-D5UE] [hereinafter Trump Dec. 22, 2020 Clemency]; White House Press Release, Statement from the Press Secretary Regarding Executive Grants of Clemency (Dec. 23, 2020), at https://trumpwhitehouse.archives.gov/briefings-statements/statementpress-secretary-regarding-executive-grants-clemency-122320 [https://perma.cc/ECA2-8HV9] [hereinafter Trump Dec. 23, 2020 Clemency]; White House Press Release, Statement from the Press Secretary Regarding Executive Grants of Clemency (Jan. 20, 2021), at https://trumpwhitehouse.archives.gov/briefings-statements/statementpress-secretary-regarding-executive-grants-clemency-012021 [https://perma.cc/B7CE-2WJS] [hereinafter Trump Jan. 20, 2021 Clemency]. For a full list of Trump's clemency grants, see U.S. Dep't of Justice, Pardons Granted by President Donald Trump (2021), at https://www.justice.gov/pardon/pardons-granted-president-donald-trump [https://perma.cc/NU5Y-EWGL] (listing pardons); U.S. Dep't of Justice, Commutations Granted by President Donald Trump (2017-2021) (2021), at https://www.justice.gov/pardon/commutations-granted-president-donald-trump-2017-2021 [https://perma.cc/AYC6-VBXE] (listing commutations).

${ }^{7}$ See U.S. Dep't of Justice, Clemency Recipients (2021), at https://www.justice.gov/pardon/clemencyrecipients [https://perma.cc/R8EE-9A5W]. 
recommendation for submission to the President in every case." 8 Though this formal pardon attorney process is not constitutionally required, it is intended to "regularize ... pardon considerations" through the application of established criteria and to protect the president from issuing questionable pardons. ${ }^{9}$ Just twenty-five of the roughly 240 pardons and commutations that Trump granted went through the pardon attorney; the rest reached him "ad hoc" through advisors in the White House. ${ }^{10}$

Trump's December 2020 decision to grant full pardons to four former Blackwater contractors-Nicholas Slatten, Paul Slough, Evan Liberty, and Dustin Heard ${ }^{11}$ - drew particular attention. Slatten was convicted of first-degree murder and the other three men were convicted of manslaughter for their roles in the 2007 Nisour Square incident, which left thirty-one Iraqi civilians dead or wounded. ${ }^{12}$ At the time of the incident, the contractors were tasked with providing security to U.S. diplomats serving in Iraq, and they claimed they acted in self-defense after their convoy came under fire during a stop. ${ }^{13}$ However, "[i]nvestigators for the military and the [Federal Bureau of Investigation (FBI)] later described the shootings, in which the contractors unleashed a blaze of gunfire and grenade explosions in a busy Baghdad square, as unprovoked and unjustified,"14 and "the men were charged in 14 of the deaths that the F.B.I. found violated rules for deadly use of force." 15 The United States would not allow the contractors to be tried in Iraqi courts, ${ }^{16}$ but U.S. proceedings took more than a decade. ${ }^{17}$ Then-Vice President Joseph Biden's announcement in 2010 that the Obama administration would appeal an early trial court decision to dismiss the charges caused certain media outlets to refer to the contractors as the "Biden Four." 18 Ultimately, in 2019, the U.S. District Court for the District of Columbia sentenced Slatten to life imprisonment ${ }^{19}$ and resentenced the other three contractors to twelve- to fifteen-year terms of imprisonment. ${ }^{20}$ Overall, the incident sparked increased

${ }^{8}$ See U.S. Dep’t of Just., Justice Manual, $\$$ 9-140.000-Pardon Attorney (Apr. 2018), at https://www.justice.gov/jm/jm-9-140000-pardon-attorney [https://perma.cc/T7FG-SCLN].

9 Jack Goldsmith \& Matt Gluck, Trump's Circumvention of the Justice Department Clemency Process, LAWFARE (Dec. 29, 2020), at https://www.lawfareblog.com/trumps-circumvention-justice-department-clemency-process.

${ }^{10}$ Kenneth P. Vogel, The Road to Clemency From Trump Was Closed to Most Who Sought It, N.Y. TIMES (Jan. 26, 2021), at https://www.nytimes.com/2021/01/27/us/politics/trump-pardons.html; see also Maggie Haberman \& Michael S. Schmidt, Trump Pardons Two Russia Inquiry Figures and Blackwater Guards, N.Y. TIMES (Dec. 22, 2020), at https://www.nytimes.com/2020/12/22/us/politics/trump-pardons.html (quoting Harvard Law School Professor Jack Goldsmith concluding that Trump's continual circumvention of standard procedures resulted in an "'unprecedented pattern of issuing self-serving pardons and commutations that advance his personal interests, reward friends, seek retribution against enemies, or gratify political constituencies”').

${ }^{11}$ Trump Dec. 22, 2020 Clemency, supra note 6.

${ }^{12}$ Falih Hassan \& Jane Arraf, Blackwater's Bullets Scarred Iraqis. Trump's Pardon Renewed the Pain., N.Y. TIMES (Dec. 23, 2020), at https:/www.nytimes.com/2020/12/23/world/middleeast/blackwater-trump-pardon.html.

${ }^{13} \mathrm{Id}$.

${ }^{14}$ Karen DeYoung, Trump Pardons Blackwater Contractors Convicted in Deaths of 14 Iraqi Civilians, WASH. POST (Dec. 22, 2020), at https://www.washingtonpost.com/national-security/trump-pardon-blackwater-contractors-iraq/ 2020/12/22/603da1f4-44b8-11eb-a277-49a6d1f9dff1_story.html.

${ }^{15}$ Hassan \& Arraf, supra note 12.

${ }^{16}$ DeYoung, supra note 14.

17 See generally United States v. Slough, No. 1:08-cr-00360 (D.D.C. Dec. 4, 2008).

${ }^{18}$ DeYoung, supra note 14; Reuters Staff, U.S. to Appeal Dismissal of Blackwater Charges_Biden, ReUTERS (Jan. 23, 2010), at https://www.reuters.com/article/uk-iraq-usa-blackwater-idUKTRE60M19N20100123.

${ }^{19}$ Minute Entry for Sentencing at 149, United States v. Slatten, No. 1:14-cr-00107 (D.D.C. Aug. 14, 2019).

${ }^{20}$ Minute Entry for Sentencing at 141, United States v. Slough, No. 1:08-cr-00360 (D.D.C. Sept. 5, 2019) 
scrutiny over the proper role of private security contractors operating in combat zones and caused friction between the United States and Iraq, eventually "play[ing] a role in helping to speed the withdrawal of U.S. forces from Iraq in 2011, after Iraqi political leaders rejected American demands for immunity for all U.S. troops." 21

In a statement announcing the pardons, the White House press secretary emphasized the contractors' prior military service and characterized the Nisour Square incident and subsequent case as follows:

These veterans were working in Iraq in 2007 as security contractors responsible for securing the safety of United States personnel. When the convoy attempted to establish a blockade outside the "Green Zone," the situation turned violent, which resulted in the unfortunate deaths and injuries of Iraqi civilians. Initial charges against the men were dismissed, but they were eventually tried and convicted on charges ranging from first degree murder to voluntary manslaughter. On appeal, the D.C. Circuit Court of Appeals ruled that additional evidence should have been presented at Mr. Slatten's trial. Further, prosecutors recently disclosed - more than 10 years after the incident - that the lead Iraqi investigator, who prosecutors relied heavily on to verify that there were no insurgent victims and to collect evidence, may have had ties to insurgent groups himself. ${ }^{22}$

The statement further indicated that the pardons were "broadly supported by the public" and nine Republican members of the House of Representatives. ${ }^{23}$ Support Raven 23, a private advocacy group that had long lobbied for the pardons, characterized the contractors as "four decorated veterans" who "were sacrificed for politics and convicted by lies."24

The Blackwater pardons brought swift condemnation from a variety of quarters. The Iraqi Foreign Ministry observed that the pardons are "inconsistent with the [U.S.] administration's declared commitment to the values of human rights, justice and the rule of law." 25 Senator Chris Murphy (D-CT) tweeted that "[p]ardoning these murderers is a disgrace," calling it "part of a plan to limit Biden's national security tools" by "greatly damag[ing] U.S.-Iraq relations, at a critical moment." 26 Former U.S. Attorney for the District of Columbia Ronald C. Machen, who oversaw the contractors' prosecution, noted the difficulties the Department of Justice had faced investigating the case in a hot combat zone and prosecuting it with more than thirty hesitant, foreign witnesses, and he lamented that the pardons had "thrown away" those efforts. ${ }^{27}$ Haider Ahmed, who was shot four times during the Nisour Square incident, explained that he testified at the contractors' trial because he

${ }^{21}$ Hassan \& Arraf, supra note 12.

${ }^{22}$ Trump Dec. 22, 2020 Clemency, supra note 6.

${ }^{23} \mathrm{Id}$.

${ }^{24}$ The Biden Four, SUPPORT Raven 23, at http://www.supportraven23.com [https://perma.cc/BT2T-ZRRS]; Karen DeYoung, Trump's Pardon of "Blackwater Four" Highlights Deep Divisions Over Iraq War, WASH. POsT (Dec. 23. 2020), at https://www.washingtonpost.com/national-security/trump-pardons-blackwater-iraq-war/2020/12/ 23/3f6bd0d8-454c-11eb-a277-49a6d1f9dff1_story.html.

${ }^{25}$ Republic of Iraq Ministry of Foreign Affairs Press Release (Dec. 23, 2020), at https://www.mofa.gov.iq/ 2020/12/?p=20049 [https://perma.cc/L38E-CD65].

${ }^{26}$ Chris Murphy (@ChrisMurphyCT), TwiTter (Dec. 23, 2020, 10:08 AM), at https://twitter.com/ ChrisMurphyCT/status/1341762622144860162?s=20.

${ }^{27}$ Hassan \& Arraf, supra note 12. 
“"thought there [wa]s a real law"” in the United States, but the pardons have caused him to ask “" $[\mathrm{w}]$ hy did I bother?"”28

Human rights groups and experts also condemned the pardons. Human Rights Watch observed that "'justice ha[d] been undone by the stroke of a pen." 29 Independent human rights experts sitting on the UN Human Rights Council's Working Group on the Use of Mercenaries commented that " $[\mathrm{t}]$ hese pardons violate [U.S.] obligations under international law and more broadly undermine humanitarian law and human rights at a global level."”30

In addition to the Blackwater pardons, Trump granted clemency to a number of associates convicted as part of Special Counsel Mueller's investigation into Russian interference in the 2016 presidential election. ${ }^{31}$ On November 25, 2020, Trump granted Flynn a full pardon for lying to the FBI. ${ }^{32}$ The White House press secretary's statement announcing the pardon criticized the investigation, declaring:

General Flynn should not require a pardon. He is an innocent man. Even the FBI agents who interviewed General Flynn did not think he was lying. Multiple investigations have produced evidence establishing that General Flynn was the victim of partisan government officials engaged in a coordinated attempt to subvert the election of 2016. These individuals sought to prevent Donald Trump from being elected to the Presidency, to block him from assuming that office upon his election, to remove him from office after his inauguration, and to undermine his Administration at every turn. ${ }^{33}$

On December 22, 2020, Trump pardoned his former foreign policy advisor George Papadopoulos and attorney Alexander van der Zwann, who had both pleaded guilty to making false statements to investigators. ${ }^{34}$ The next day, Trump issued pardons to his former advisor Roger Stone, Jr., who had been convicted of obstruction of proceedings, witness tampering, and five counts of false statements, ${ }^{35}$ and to his former campaign chairman Paul Manafort, who had pleaded "guilty to conspiracy to defraud the United States and obstruct justice related to his

\footnotetext{
${ }^{28}$ Mustafa Salim \& Louisa Loveluck, In Iraq, Trump’s Blackwater Pardons Meet with Cynicism, Fatigue, WASH. PosT (Dec. 23, 2020), at https://www.washingtonpost.com/world/middle_east/iraq-blackwater-military-contractors-pardons/2020/12/23/062ee814-44bb-11eb-ac2a-3ac0f2b8ceeb_story.html.

${ }^{29}$ DeYoung, supra note 24.

${ }^{30}$ US Pardons Blackwater Guards: An "Affront to Justice" - UN Experts, UN NEWs (Dec. 30, 2020), at https:// news.un.org/en/story/2020/12/1081152.

${ }^{31}$ For information on the Mueller investigation and related prosecutions, see U.S. Dep't of Justice, Special Counsel's Office (2021), at https://www.justice.gov/sco.

32 Flynn Pardon, supra note 6; Charlie Savage, Citing Trump's Pardon, Judge Dismisses Case Against Michael Flynn, N.Y. Times (Dec. 8, 2020), at https://www.nytimes.com/2020/12/08/us/politics/michael-flynn-case-dismissed.html.

${ }^{33}$ Flynn Pardon, supra note 6. As a result of the pardon, Judge Emmet G. Sullivan of the U.S. District Court for the District of Columbia dismissed the charges against Flynn; Sullivan had previously stated that the Department of Justice's arguments for dismissing the case were "dubious to say the least." Savage, supra note 32.

34 Trump Dec. 22, 2020 Clemency, supra note 6; Haberman \& Schmidt, supra note 10.

${ }^{35}$ Trump Dec. 23, 2020 Clemency, supra note 6; United States v. Stone, No. 19-018 (ABJ), 2020 WL 917295, at *1 (D.D.C. 2020). Trump had previously commuted Stone's sentence on July 10, 2020. White House Press Release, Statement from the Press Secretary Regarding Executive Grant of Clemency for Roger Stone, Jr. (July 10, 2020), at https://trumpwhitehouse.archives.gov/briefings-statements/statement-press-secretary-regarding-executive-grant-clemency-roger-stone-jr [https://perma.cc/YTC8-RSAB].
} 
undisclosed lobbying for a pro-Russian politician and political party in Ukraine." 36 Trump also granted a full pardon to Paul Erickson, who is the former boyfriend of Russian agent Maria Butina and was convicted of a financial crime as a result of the Mueller investigation. ${ }^{37}$

Additionally, on his last day in office, Trump pardoned Aviem Sella, an Israeli citizen who recruited former U.S. Navy intelligence analyst Jonathan Pollard to spy for Israel in the 1980s. ${ }^{38}$ The White House noted that "the Prime Minister of Israel Benjamin Netanyahu, Israeli Ambassador to the United States Ron Dermer, the United States Ambassador to Israel David Friedman, and Miriam Adelson" supported the request and that Israel "has issued a full and unequivocal apology [for its involvement], and has requested the pardon in order to close this unfortunate chapter in U.S.-Israel relations."39

Also notable are pardons Trump ultimately did not issue. In particular, Trump chose not to pardon WikiLeaks founder Julian Assange, whose extradition to the United States on espionage charges a British judge recently blocked. ${ }^{40}$ Trump also did not pardon himself, his adult children, his son-in-law Jared Kushner, his personal attorney Rudolph W. Giuliani, or participants in the January 6, 2021 riot at the U.S. Capitol building. ${ }^{41}$

\section{INTERNATIONAL CRIMINAL LAW}

\section{U.S. Arrest of Former Mexican Defense Minister on Drug Charges Poses Challenges for Future Counter-Narcotics Cooperation}

doi:10.1017/ajil.2021.14

In October 2020, the United States arrested former Mexican Defense Secretary General Salvador Cienfuegos Zepeda on drug conspiracy charges, accusing him of accepting bribes to aid a Mexican cartel in evading law enforcement and transporting drugs into the United

\footnotetext{
36 Trump Dec. 23, 2020 Clemency, supra note 6; Rachel Weiner, Spencer S. Hsu \& Matt Zapotosky, Paul Manafort Released from Prison, Granted Home Confinement Due to Coronavirus Fears, Wash. Post (May 13, 2020), at https:/www.washingtonpost.com/national-security/paul-manafort-granted-home-confinement-due-to-coronavirus-fears/2020/05/13/7746835c-8320-11ea-ae26-989cfce1c7c7_story.html.

37 Trump Jan. 20, 2021 Clemency, supra note 6; Maggie Haberman, Kenneth P. Vogel, Eric Lipton \& Michael S. Schmidt, With Hours Left in Office, Trump Grants Clemency to Bannon and Other Allies, N.Y. Times (Jan. 20, 2021), at https://www.nytimes.com/2021/01/20/us/politics/trump-pardons.html.

38 Trump Jan. 20, 2021 Clemency, supra note 6; Trump Pardons Israeli Officer Who Enlisted Spy Pollard, Assoc. PRESS (Jan. 20, 2021), at https://apnews.com/article/donald-trump-israel-jonathan-pollard-benjamin-netanyahuunited-states-c3d2e46029b23e7bdaa5bda6ec878247.

39 Trump Jan. 20, 2021 Clemency, supra note 6.

${ }^{40}$ Kenneth P. Vogel, With Trump Presidency Winding Down, Push for Assange Pardon Ramps Up, N.Y. Times (Jan. 10, 2021), at https:/www.nytimes.com/2021/01/10/us/politics/assange-trump-pardon.html.

${ }^{41}$ Carol D. Leonnig, Josh Dawsey \& Rosalind S. Helderman, Trump Prepares to Offer Clemency to More Than 100 People in His Final Hours in Office, WasH. POsT (Jan. 18, 2021), at https://www.washingtonpost.com/politics/ trump-pardons-final-days/2021/01/17/7a57969c-5905-11eb-a976-bad6431e03e2_story.html; Maggie Haberman \& Michael S. Schmidt, Trump Has Discussed With Advisers Pardons for His 3 Eldest Children and Giuliani, N.Y. Times (Dec. 1, 2020), at https://www.nytimes.com/2020/12/01/us/politics/rudy-giuliani-pardon.html; Alan Feuer \& Nicole Hong, "I Answered the Call of My President": Rioters Say Trump Urged Them On, N.Y. Times (Jan. 17, 2021), at https://www.nytimes.com/2021/01/17/nyregion/protesters-blamingtrump-pardon.html.
} 